\title{
Konrad Rzemieniecki
}

Wrocław

\section{Perspektywy badań nad populacją i rodziną województwa kijowskiego w XVIII wieku}

Tereny dawnego województwa kijowskiego (złożonego z powiatów: kijowskiego, żytomierskiego i owruckiego) stanowią specyficzny i zróżnicowany region geograficzny, co nie pozostawało bez wpływu na kształt miejscowego osadnictwa oraz wielkość i strukturę rodziny i jej gospodarstwa domowego. W granicach staropolskiej Kijowszczyzny można było wyróżnić trzy główne i odrębne geograficznie obszary. Na północy leżą rozległe mokradła pokryte gęstymi lasami nazywane Polesiem ukraińskim, a zawierające się w granicach wyznaczonych przez rzeki Prypeć, Słoweczną i Usz. W XVIII wieku był to obszar dość rzadkiego osadnictwa w niewielkich osadach rozrzuconych po lasach oraz skupionych na kilku ,wyspach” rejonów mniej podmokłych i bardziej sprzyjających gęstszemu zaludnieniu. Większość tutejszych miejscowości była niewielka, a w źródłach najczęściej określane były jako futory, huty i słobody. Osadnictwu nie sprzyjał lokalny klimat charakteryzujący się dużą wilgotnością połączony ze szkodliwymi wyziewami bagiennymi. Ludność najczęściej zajmowała się gospodarką leśną, wytopem żelaza z rud darniowych, a w sprzyjających warunkach glebowych również rolnictwem. Osadnictwo tego obszaru stosunkowo często było nietrwałe, co widoczne jest w taryfach podatkowych z tego okresu. Na południe od Polesia, w umownym trójkącie między Żytomierzem, Kijowem i Białą Cerkwią, leżą najbogatsze rejony województwa charakteryzujące się wysokim zaludnieniem, gęstą siecią osadniczą i żyznymi glebami. Trzeci region to południowo-wschodnia część Kijowszczyzny, w pasie ziemi nad Dnieprem biorącym 
swój początek na wschód od Taraszczy, gdzie dominował krajobraz stepowy, a gleby często bywały piaszczyste 1 .

Należy również zaznaczyć, że województwo kijowskie wchodziło w XVIII wiek w dużym stopniu zniszczone i wyludnione przez wydarzenia poprzedniego stulecia, począwszy od powstania Bohdana Chmielnickiego, poprzez wojnę polsko-rosyjską i liczne najazdy tatarskie, po niepokoje społeczne i działalność różnego rodzaju grup rozbójniczych nazywanych tu hajdamakami. W pierwszej połowie XVIII wieku, szczególnie od trzeciej dekady, województwo stało się terenem znacznej kolonizacji, jak się wydaje głównie wewnętrznej, skutkującej zakładaniem licznych nowych wsi i słobód przy wsiach już istniejących. W drugiej połowie stulecia nowe wsie były rzadkością, za to przy istniejących osadach wciąż powstawały kolejne słobody.

Struktura etniczna i religijna ludności województwa kijowskiego w XVIII wieku nie jest szczegółowo znana. Etnosem dominującym była tu ludność ruska obrządku greckokatolickiego z niewielkim udziałem rzymskokatolickiej ludności polskiej i zamieszkującej głównie większe ośrodki ludności żydowskiej. Zarówno ludność polska, jak i żydowska najprawdopodobniej nie stanowiły więcej niż po około $10 \%$ ogółu. Ale jedynie dla ludności żydowskiej dysponujemy częściowymi danymi co do jej liczby, którą można oszacować na podstawie taryfy pogłównego z $1775 \mathrm{roku}^{2}$. Poza wymienionymi grupami etnicznymi i religijnymi obszar ten zamieszkiwała nieliczna społeczność staroobrzędowców.

Powyższy zarys sytuacji geograficzno-gospodarczo-osadniczej województwa daje możliwość regionalnych, porównawczych badań nad populacją, wielkością i strukturą rodziny oraz ruchem naturalnym ludności z uwzględnieniem kilku istotnych elementów wpływu, przede wszystkim w opozycji północ-południe. Chodzi tu przede wszystkim o ukształtowanie terenu i wynikającego z tego sposobu organizacji gospodarki w majątkach ziemskich, w tym organizacji pracy miejscowej ludności. Południe charakteryzowało się przede wszystkim w miarę jednolitą organizacją uprawy ziemi opartą na pańszczyźnie, północ, z racji ukształtowania terenu, cechowała się bardziej zróżnicowanymi systemami dostosowanymi do potrzeb poszczególnych majątków. Niewątpliwie na Polesiu (cały powiat owrucki), z racji niewielkiej ilości ziem uprawnych i większego znaczenia gospodarki leśnej, nie było zbyt wielkiego zapotrzebowania na gospodarstwa pełnorolne (kmiece, półkmiece, czasami zagrodnicze), a częściej można było

${ }^{1}$ Stownik Geograficzny Królestwa Polskiego i innych krajów stowiańskich, red. Filip Sulimierski, Bronisław Chlebowski, Władysław Walewski, t. IV, Warszawa 1883, s. 92; t. VIII, Warszawa 1887, s. 586; Zygmunt Gloger, Geografia historyczna ziem dawnej Polski, Kraków 1900 , s. 256-257.

${ }^{2}$ Центральний державний історичний архів України, м. Київ, fond 11 (Sąd grodzki żytomierski), opys 1 , sprawa 63 , k. 29-33v. 
spotkać gospodarstwa czynszowe. System gospodarczy miał tu istotny wpływ na wielkość i strukturę rodziny biologicznej, jak i jej gospodarstwa domowego, które powiązane były $\mathrm{z}$ areałem uprawianej ziemi. W lokalnej rzeczywistości znaczenie mogła mieć również jakość miejscowych gleb: nieurodzajnych i bagiennych na Polesiu i żyznych czarnoziemów na południu. Warunki geograficzne miały również wpływ na ogólne zaludnienie poszczególnych rejonów, gęstość zaludnienia czy wielkość poszczególnych osad.

Czynnikiem, który niewątpliwie zaburzał miejscową strukturę i wielkość rodziny oraz gospodarstwa, była również intensywna kolonizacja wewnętrzna województwa. Tradycyjne gospodarstwo domowe na tym obszarze związane było z rodziną wielopokoleniową, złożoną z kilku par małżeńskich, najczęściej rodziców z dorosłymi dziećmi z własnymi rodzinami ${ }^{3}$. Proces kolonizacyjny najprawdopodobniej upraszczał te struktury, powodując, że dorosłe dzieci z rodzinami opuszczały rodzinne gospodarstwa i osiadały na własnych w nowo założonych wsiach lub słobodach. Proces kolonizacyjny pobudzał również znaczną ruchliwość ludności - zarówno pożądaną przez właścicieli ziemskich, gdy zakładali nowe osady lub nowe gospodarstwa w istniejących już wsiach, jak i niechcianą, gdy dotykał ich problem zbiegostwa poddanych do innych dóbr, co prowadziło do licznych i widocznych w miejscowych księgach grodzkich procesów o zwrot poddanych.

Zaznaczone dwa czynniki, geograficzny i kolonizacyjny, miały dostrzegalny wpływ nie tylko na strukturę i wielkość rodziny i jej gospodarstwa, ale również na inne zjawiska demograficzne, jak wiek zawierania małżeństw, długość życia i trwania małżeństwa, liczbę urodzonych w rodzinie dzieci oraz ich przeżywalność, umieralność okołoporodową i szereg innych kwestii, stanowiących przedmiot zainteresowania demografii historycznej, które jak dotąd w literaturze, odnośnie do opisywanego regionu, nie były podejmowane.

Rozważania nad perspektywami badań nad stanem i strukturą populacji osiemnastowiecznej Kijowszczyzny (podobnie jak innych regionów) oraz charakterystycznej dla niej rodziny i gospodarstwa domowego należy zacząć ustalenia podstawy źródłowej umożliwiającej przeprowadzenie badań oraz stanu je zachowania. W wypadku województwa kijowskiego w ostatnim stuleciu I Rzeczypospolitej, do dyspozycji historyków pozostaje bogaty, choć rozproszony,

\footnotetext{
${ }^{3}$ Микола Крикун, Населення домогосподарств у Житомирському повіті Київського воєводства 1791 року, [w:] Микола Крикун, Воєводства Правобережної України у XVI-XVIII століттях. Статті $i$ матеріали, Львів 2012, s. 569; Юрій В. Волошин, Розкольницькі слободи на території Північної Гетьманщини $y$ XVIII ст. (історико_демографічний аспект), Полтава 2005, s. 77; Konrad Rzemieniecki, Struktura i wielkość gospodarstw rodzinnych staroobrzędowców w powiecie żytomierskim w guberni wotyńskiej w końcu XVIII wieku, „Roczniki Dziejów Społeczno-Gospodarczych" (w druku).
} 
zespół dokumentacji wytworzonej na potrzeby skarbu państwa i województwa, administracji majątkowej oraz kościelnej.

Podstawowym źródłem do badań zaludnienia województwa kijowskiego w XVIII wieku są rejestry podatku podymnego (w źródle zwane taryfami), których stan zachowania umożliwia analizę procesu zmian zaludnienia w całym stuleciu. Podatek ten uchwalany był przez sejmy, a później także lokalne sejmiki, począwszy od roku 1629. Jednak wykorzystując ten rodzaj dokumentacji skarbowej należy pamiętać, że aż do czasu likwidacji tego podatku na Sejmie Koronacyjnym w grudniu 1764 roku i jego przywrócenia w nowej formie przez Sejm ekstraordynaryjny warszawski (Sejm Rozbiorowy) w 1775 roku$^{4}$, w osiemnastowiecznych rejestrach podatku podymnego jeden dym był jednostką obrachunkową i nie oznaczał jednej chałupy. Informację o tym, ile chałup zawierało się $\mathrm{w}$ jednym dymie, zazwyczaj bez problemu można ustalić na podstawie samego rejestru lub odnaleźć w laudum sejmiku, na którym uchwalono pobór podatku.

Punktem wyjścia do takich badań mógłby być rejestr z 1683 roku obejmujący powiaty żytomierski i owrucki, niestety bez kijowskiego ${ }^{5}$. Pierwszymi osiemnastowiecznymi taryfami przedstawiającymi wartość badawczą są dokumenty pochodzące z 1724 roku dotyczące powiatów kijowskiego i żytomierskiego ${ }^{6}$. Kolejne, już dla całego województwa, pochodzą z lat 1734, 1754 i 17757. Z końca stulecia pochodzi sumariusz „ofiary 10 i 20 grosza” ${ }^{\circ}$ wymagający przeliczenia sumy złotowej podatku na liczbę domów oraz niekompletny podatek podymny z 1790 roku $^{9}$ zachowany dla części powiatów kijowskiego i żytomierskiego. Mankamentem taryf sprzed 1775 roku jest nieujmowanie w nich chałup zamieszkanych przez ludność będącą na tzw. „usłudze dworskiej”, które, jak wynika z zachowanych lustracji części powiatu żytomierskiego z 1731 i 1748 roku, stanowią około $15 \%$ chałup wiejskich, we wsiach, gdzie stały dwory i folwarki.

${ }^{4}$ Volumina Legum (dalej: VL), t. 7, s. 146; t. 8, s. 88, Petersburg 1860.

${ }^{5}$ Архив Юго-Западной России, издаваемый Комиссией для разбора древних актов, состоящей при Киевском, Подольском и Волынском генерал-губернаторе. Часть седьмая. Том I. Акты о заселении Юго-Западной России, Киев 1886, s. 487-508.

${ }^{6}$ Taryfy podatku podymnego, lauda sejmikowe i lustracje województwa kijowskiego z pierwszej połowy XVIII wieku, oprac. Konrad Rzemieniecki przy współpracy Eugeniusza Czernieckiego, Przemysława Jóźwikiewicza i Violetty Szymczyk, Biała Cerkiew 2015.

${ }^{7}$ Центральний державний [2], fond 11 (Sąd grodzki żytomierski), opys 1, sprawa 63; tamże, fond 2 (Sąd grodzki kijowski), opys 1, sprawa 78; Taryfy podatku podymnego [6]; Taryfa podatku podymnego województwa kijowskiego 1754 roku, oprac. Konrad Rzemieniecki, wstęp na język ukraiński przetłumaczył Eugeniusz Czerniecki, Biała Cerkiew 2015.

${ }^{8}$ Ofiara na wojsko z dóbr ziemskich, tak świeckich, jako i duchownych województwa i powiatu kijowskiego jako też powiatów żytomierskiego i owruckiego, roku 1789 go uczyniona, Zakład Narodowy im. Ossolińskich, Dział Rękopisów, sygn. 500/III, s. 1-90.

${ }^{9}$ Центральний державний [2], fond 8 (Komisja porządkowa cywilno-wojskowa powiatu żytomierskiego), opys 1 , sprawa 9. 
Kolejnym wartym odnotowania źródłem jest spis parafii greckokatolickiej metropolii kijowskiej przygotowany na polecenie metropolity Jasona Smogorzewskiego w 1782 roku, obejmujący wszystkie dekanaty cerkwi greckokatolickiej województw kijowskiego i bracławskiego, w którym wyszczególniono każdą miejscowość z cerkwią parafialną z uwzględnieniem liczby domów oraz oddzielnie parafian dorosłych (,sposobnych do spowiedzi”) i dzieci ${ }^{10}$. Dokument ten daje obraz właściwie całościowego zaludnienia tych województw. Poza spisem zachowały się również protokoły poszczególnych wizytacji z lat 1780-1788.

Wycinkowym materiałem źródłowym, obejmującym jednak znaczny obszar, są lustracje królewszczyzn województwa kijowskiego z 1765 i 1789 roku $^{11}$. Oba dokumenty zawierają informacje o liczbie chałup znajdujących się we wsiach królewskich, z których wartościowszą dla badań populacyjnych jest lustracja z 1789 roku zawierająca imienny spis gospodarzy. Lustracje mogą być ważnym materiałem dla analiz szczegółowych dotyczących głównie powiatu kijowskiego, w którym znajdowała się większość królewszczyzn tego województwa (starostwa czehryńskie, czerkaskie, bohusławskie, korsuńskie) zajmujących niemal zwarty pas ziemi wzdłuż Dniepru. Kolejnym źródłem „wycinkowym” mogą stać się inwentarze poszczególnych dóbr. Jednak ze względu na znaczne rozproszenie geograficzne i chronologiczne zachowanych do dnia dzisiejszego inwentarzy, podobnie jak lustracje królewszczyzn, mogą stanowić one podstawę badań szczegółowych niewielkich obszarów lub badań kontrolnych w odniesieniu do innych rodzajów źródeł. Lustracje i inwentarze mogą stać się również, obok spisów ludności, materiałem umożliwiającym przeliczenie sumy złotowej podatku w „ofierze 10 i 20 grosza" na liczbę domów oraz w miarę dokładnego ustalenia odsetka chałup „na dworskiej usłudze”, pomijanych w taryfach podatku podymnego.

Kolejnymi ważnymi źródłami będącymi podstawą zarówno dla badań nad populacją, jak i nad rodziną, są spisy ludności. W wypadku województwa kijowskiego w XVIII wieku przeprowadzono dwa państwowe spisy ludności, po których do dnia dzisiejszego zachowały się materiały, czyli spisy Komisji porządkowych cywilno-wojskowych z 1791 roku oraz rosyjski rewizyjny spis ludności z 1795 roku (tzw. V rewizja). Spisy Komisji porządkowych zachowały się jedynie dla powiatu żytomierskiego w postaci jednej księgi zawierającej informacje dla około $10 \%$ miejscowości powiatu ${ }^{12}$. Znacznie lepszą reprezentację geograficzną i liczbową reprezentuje rewizyjny spis ludności z 1795 roku. Zachowały się spisy mieszkańców byłych już wówczas powiatów kijowskiego

${ }^{10}$ Socjografia kościoła grekokatolickiego na bracławszczyźnie i kijowszczyźnie w 1782 roku, opracował i wydał Marian Radwan, Lublin 2004.

${ }^{11}$ Archiwum Główne Akt Dawnych, Archiwum Skarbu Koronnego, dział XLVI, sygn. 3, 4.

${ }^{12}$ Центральний державний [2], fond 8 (Komisja porządkowa cywilno-wojskowa powiatu żytomierskiego), opys 1 , sprawa 15 . 
i żytomierskiego. Podział administracyjny wprowadzony przez Rosjan po 1793 roku rozdzielił staropolskie województwo kijowskie na gubernie kijowską (powiat kijowski) i zasławską (izajasławską), przemianowaną w 1795 roku na wołyńską (powiaty żytomierski i owrucki). Zakres terytorialny i liczba zachowanych spisów nie są mi obecnie znane. Jednak tylko w jednym archiwum w Żytomierzu spisy z 1795 roku to łącznie 11 tomów o kilkuset stronach każdy, zawierające informacje o mieszkańcach około 250 miejscowości, co w przybliżeniu stanowi jedną trzecią osad przedrozbiorowego powiatu żytomierskiego. Spisy z pozostałych osad są obecnie rozproszone i przechowywane w archiwach wojewódzkich w Kijowie, Żytomierzu i Winnicy.

Dla obszaru tego najprawdopodobniej nie zachowały się osiemnastowieczne spisy spowiednicze i spisy parafialne. Podczas kilku wizyt w Centralnym Archiwum Historycznym Ukrainy w Kijowie i wojewódzkim w Żytomierzu nie udało mi się odnaleźć tego typu materiałów, nie informują o nich również ukraińskie inwentarze archiwalne.

Stan zachowania osiemnastowiecznych ksiąg metrykalnych różnych wyznań można oceniać w dwóch perspektywach: fizycznego zachowania oraz jakości (chronologii) zachowania. W sensie fizycznym zachowało się całkiem sporo ksiąg metrykalnych, natomiast przy rozróżnieniu na poszczególne wyznania i uwzględnieniu ciągłości i długości prowadzonej rejestracji, znacznie tracą na wartości. Charakterystyczną cechą dotyczącą osiemnastowiecznych ksiąg metrykalnych jest fakt, że większość zachowało się dla ostatnich dekad tego stulecia, często o krótkiej ciągłości zapisów. Większość z nich przechowywana jest w zasobach archiwów państwowych w Żytomierzu, Kijowie, Winnicy, Czerkasach i Chmielnickim. Są to księgi rzymskokatolickie i prawosławne. Te ostatnie, ze względu na politykę władz rosyjskich, dla ich najwcześniejszych lat można utożsamiać z księgami cerkwi greckokatolickiej. Wiele wskazuje na to, że w licznych parafiach „przenoszonych” w XVIII i XIX wieku z obrządku unickiego na prawosławie kontynuowano zapisy metrykalne w księgach rozpoczętych jeszcze w „starej” cerkwi. Dla tego okresu nie zachowały się księgi religii mojżeszowej i staroobrzędowców.

Rzymskokatolickie księgi metrykalne przetrwały tylko z nielicznych parafii. Największa ich liczba jest obecnie przechowywana w archiwum w Żytomierzu. $\mathrm{Z}$ zachowanych materiałów $\mathrm{z}$ około 22 parafii w dziewięciu rejestracja rozpoczyna się w ostatnich pięciu latach XVIII wieku, w przypadku 8 innych - przed 1781 rokiem. W kontekście stanu zachowania metryk tego obszaru warto bliżej opisać trzy z nich. Metryki parafii w Byszowie (50 km na zach. od Kijowa) zachowały się dla lat 1733-1827 (chrzty), 1735-1817 (śluby) i 1778-1817 (pogrzeby), parafii w Mosznej (20 km na płn.-zach. od Czerkas) dla lat 1756-1820 (urodzenia, śluby, zgony) i parafii w Rzyszczowie (ok. 90 km na płd. od Kijowa) dla lat 1765-1814 
(urodzenia, śluby, zgony). Poza archiwum żytomierskim osiemnastowieczne księgi metrykalne dwóch parafii znajdują się jeszcze w archiwum miasta Kijowa i archiwum w Winnicy.

Prawosławne, osiemnastowieczne księgi metrykalne z obszaru staropolskiego województwa kijowskiego znajdują się głównie w archiwach w Żytomierzu, Chmielnickim i Czerkasach. W Żytomierzu można również odnaleźć nieliczne księgi greckokatolickie. Księgi prawosławne archiwum żytomierskiego zachowały się dla kilkuset parafii. Są to głównie metryki z ostatnich pięciu lub dziesięciu lat, często bez zachowanej ciągłości nawet $\mathrm{w}$ tak krótkim okresie czasu. $\mathrm{W}$ archiwum $\mathrm{w}$ Chmielnickim zgromadzonych jest kilkadziesiąt ksiąg $\mathrm{z}$ terenu obecnego powiatu taraszczańskiego, ale z zapisami tylko dla 1796 roku. Znacznie wartościowsze są księgi przechowywane w archiwum czerkaskim. Tu również większość metryk parafialnych (około 100 parafii) pochodzi z ostatnich pięciu lat osiemnastego stulecia, ale zdarzają się również starsze, choć nieliczne. Najstarsze metryki pochodzą z Korsunia, zachowane dla lat 1737-1759 (chrzty, śluby, pogrzeby) oraz z Kaniowa, zachowane dla lat 1751-1821 (chrzty), 1752-1756 i 1758-1821 (śluby), 1778-1819 (pogrzeby) ${ }^{13}$.

Przedstawiony powyżej opis stanu zachowania ksiąg metrykalnych obszaru staropolskiego województwa kijowskiego w XVIII wieku dotyczy tylko zasobu archiwów państwowych. Najprawdopodobniej księgi metrykalne można odnaleźć również w bibliotekach naukowych i lokalnych muzeach, a także zespołach poklasztornych w archiwach państwowych.

Spróbujmy pokrótce odpowiedzieć pytanie - jaka, wobec przedstawionego powyżej stanu zachowania źródeł, rysuje się perspektywa badań nad populacją, ruchem naturalnym ludności i rodziną województwa kijowskiego w XVIII wieku. Zachowaną podstawę źródłową należy uznać za wystarczającą do podjęcia badań z zakresu demografii historycznej. Bogaty ilościowo i różnorodny materiał badawczy umożliwia jego wzajemną weryfikację i wypracowywanie szczegółowych metod analitycznych. Jako przykład takich możliwości i potrzeb można wskazać wykorzystanie taryf podatku podymnego jako podstawy do badania stanu populacji. Jak zaznaczyłem wcześniej, podatkowi nie podlegały chałupy ludności świadczącej różne usługi na rzecz dworu, których odsetek można ustalić przy pomocy inwentarzy poszczególnych majątków i lustracji królewszczyzn, wymieniających wszystkie zabudowania mieszkalne. Liczbę chałup mieszkalnych znamy również ze spisu Smogorzewskiego. Problem liczby mieszkańców pojedynczej chałupy, jak i również liczby chałup we wsi, pozwalają rozwiązać spisy

\footnotetext{
${ }^{13}$ Warto również zaznaczyć, że w archiwum w Czerkasach znajdują się księgi metrykalne 11 parafii prawosławnych z powiatu złotnickiego leżącego po lewej stronie Dniepru, a więc poza obszarem zainteresowania, których wpisy rozpoczynają się w 1734 roku lub w latach 60 . XVIII wieku i często zachowują ciągłość przez kilkadziesiąt lat.
} 
ludności przeprowadzone dwukrotnie w końcu XVIII wieku, przez co można je wzajemnie weryfikować. Szczególnie zasobną w źródła statystyczne jest druga połowa stulecia, nie mniej stan zachowanych materiałów pozwala na szczegółową analizę stanu i dynamiki zmian zaludnienia całego regionu w kilku przekrojach chronologicznych $(1734,1754,1775,1789)$ z możliwością przeprowadzenia badań z uwzględnieniem końca XVII wieku jako punktu wyjścia i odniesienia.

Także perspektywa badań nad strukturą i wielkością rodziny i gospodarstw domowych różnych grup społecznych i etnicznych wygląda dość obiecująco. Jak wcześniej zaznaczyłem, dla obszaru tego zachowały się materiały dwóch spisów ludności przeprowadzonych przez władze Rzeczypospolitej i Rosji. W wypadku spisu rosyjskiego z 1795 roku zachowany materiał obejmuje znaczny obszar terytorium byłego województwa kijowskiego i dzięki temu możliwe będą szerokie analizy porównawcze zarówno wewnątrz jego granic, jak i szerzej - obejmujące również pozostałe prowincje Cesarstwa. Wstępna analiza wybranych pojedynczych spisów, zarówno tych z 1791, jak i z 1795 roku pozwala stwierdzić zadawalającą ich wartość merytoryczną, a wyjątkowa sytuacja zachowania obu spisów pozwala również zestawić i porównać dokonania statystyczne administracji obu państw. Oba spisy zawierają informacje o wieku (deklarowanym) spisywanych osób, ich pozycji wewnątrz rodziny i w gospodarstwie, zaś w rosyjskich znajdujemy również ogólne określenie wykonywanych zajęć gospodarza. Spisy rosyjskie, w odróżnieniu od polskich, mają też niestety dwa istotne mankamenty mogące nieco utrudniać ich wykorzystanie w szczegółowych badaniach. Znacznie utrudniającym szczegółowe analizy na poziomie poszczególnych gospodarstw, gdyby chcieć badać proces długiego trwania z wykorzystaniem spisów z kolejnych lat, jest podział na ludność osiadłą i nieosiadłą, który w praktyce sporządzania poszczególnych spisów prowadził do wyłączenia z gospodarstw wszystkich komorników i parobków i spisania ich osobno na końcu, często bez zaznaczenia, $\mathrm{w}$ jakim gospodarstwie mieszkali. Drugim istotnym problemem jest podział i sporządzanie osobnych spisów dla różnych kategorii ludności, np. w spisach wiejskich najczęściej występują wolni osadnicy, chłopi pańszczyźniani, szlachta, stużba cerkiewna, różni, co powoduje, że w skrajnych sytuacjach trzeba zebrać kilka spisów, by złożyć materiał dla jednej wsi. Trudności w badaniach szczegółowych struktury gospodarstw nie powinny być jednak problemem w szerokim ujęciu statystycznym obejmującym dane ze spisów setek wsi i miast.

$\mathrm{W}$ porównaniu $\mathrm{z}$ możliwościami prowadzenia badań nad populacją oraz strukturą i wielkością rodzin i gospodarstw domowych perspektywy przyszłych analiz podejmujących zagadnienia ruchu naturalnego, jak i dotyczące rodziny, opartych na księgach metrykalnych, wyglądają znacznie skromniej. Księgi metrykalne o długich ciągach zapisów zachowały się tylko dla nielicznych parafii, a większość zapisów z innych zachowanych ksiąg dotyczy tylko końca stulecia. 
Właściwie tylko dla kilku parafii można przeprowadzić gruntowne analizy obejmujące kilkadziesiąt lat XVIII wieku, pozwalające na rekonstrukcję rodzin i zbadanie takich zagadnień, jak dzietność małżeńska, wiek kobiet przy kolejnych porodach, poczęcia przedślubne czy długość trwania małżeństwa i wdowieństwa. Znacznie lepiej, choć w krótkich ciągach chronologicznych, wygląda sprawa badań nad ruchem naturalnym, czyli wiekiem i stanem cywilnym nowożeńców, liczbą i sezonowością ślubów, zgonów i narodzin, mobilnością terytorialną ludności, strukturą zgonów pod względem płci i wieku. Odpowiedzi na część pytań dotyczących ruchu naturalnego ludności znajdziemy również w spisach ludności, w których znajdujemy informacje o strukturze ludności według płci, wieku i stanu cywilnego.

Znaczną poprawę możliwości badań demograficznych daje przekroczenie granicy XVIII wieku i wykorzystanie zapisów metrykalnych z początku XIX wieku, zwłaszcza, że w tym okresie nie zaszły istotne procesy ekonomiczne mogące wpłynąć na zachowania demograficzne szerokich mas ludności. Przekroczenie granicy stulecia poszerzy bazę ksiąg metrykalnych o co najmniej kilkadziesiąt ksiąg o długich ciągach rejestracji metrykalnej.

Podsumowując rozważania o perspektywach badań nad populacją i rodziną województwa kijowskiego w XVIII wieku można stwierdzić, że terytorialny, chronologiczny i ilościowy stan zachowania źródeł najlepiej rokuje dla badań nad zaludnieniem regionu. Trudno będzie zebrać materiał spisowy i metrykalny w celu zbadania opozycji północ-południe z racji słabego zachowania źródeł dotyczących powiatu owruckiego. Prawdopodobnie nie uda się również uwzględnić czynnika kolonizacji wewnętrznej w badaniach nad rodziną i ruchem naturalnym ludności, ponieważ zachowane materiały archiwalne dotyczą głównie ostatniego dziesięciolecia XVIII wieku, kiedy proces kolonizacyjny dobiegał końca. Należy jednak podkreślić, że pomimo nierówności zachowania podstawy źródłowej, daje ona sporo możliwości analizy większości potencjalnych kwestii badawczych, szczególnie w odniesieniu do drugiej połowy tego stulecia.

\section{Prospects of the Research on the Population and Family of the Kiev Voivodeship of the $18^{\text {th }}$ Century}

\section{Summary}

The article assesses the prospects of the research on the population and family of the Kiev Voivodeship in the $18^{\text {th }}$ century. The article has been based on the analysis of archival existing materials, which potentially might become a basis for such research (birth and death registers of various religions, censuses, state tax tables). The diversity and 
quantity of the research material makes it possible to work out detailed analytical methods. The second half of the century is especially rich in sources, and the condition of the existing materials allows a detailed analysis of the state and dynamics of changes in the population of the whole region at several points of time. Prospects of the research on the structure and size of the family and household of various social and ethnic groups seem promising. Among other things the materials concerning two censuses carried out by the Polish and Russian authorities have survived. In spite of the territorial and chronological incompatibility of the materials they offer many possibilities to analyse most of the potential research questions, especially the ones concerning the second half of the century.

Keywords: the Kiev Voivodeship, the $18^{\text {th }}$ century, the size and structure of the family, population, natural movement, birth and death registers, state tax tables, censuses 